\title{
プラーク細菌表面の微細線維状構造物および同構造物によって 凝集した細菌の電子顕微鏡的観察
}

\author{
小川真喜子竹内宏 \\ 朝日大学歯学部口腔病理学講座 \\ (主任：竹内 宏教授) \\ (平成 10 年 5 月 14 日受付)
}

\section{Electron Microscopic Observation of Fine Fibrilar Structures on Plaque Bacterial Cell Walls and the Structure-Induced Bacterial Aggregation}

\author{
Makiko Ogawa and Hiroshi Takeuchi
}

Department of Oral Pathology, School of Dentistry, Asahi University

1851 Hozumi, Hozumi-cho, Motosu-gun, Gifu 501-0296, Japan

(Chief : Prof. Hiroshi Takeuchi)

In order to clarify the aggregation mediated by their fibrilar structures on the cell wall surfaces of plaque bacteria, human supragingival dental plaque were ultrastructurally examined.

Samples were collected from native tooth enamel (upper and lower first molar) over one to seven days after suspension of tooth cleaning. The specimens were prepared for electron microscopic observation by means of freeze-substitution method which was useful in examining the fine fibrilar and membranous structures.

The fibrilar structures of bacterial cell walls were classified into three types according to their characteristics of distribution as follows: 1) peritrichous type fibrils protruding throughout the whole circumference of bacterial cell wall surface ;2) localized type fibrils protruding from a portion of the surtace; 3) mixed type fibrils protruding uncontinuously from several parts of the surface.

Abundant peritrichous type cells were recognized in most bacteria of one to three day specimens, and refleced their unique structure. Tight cell-to-cell aggregation between homogeneous and/or heterogeneous species in all these specinens was observed. However, qualitative and quantitative declines in species with fibrilar structures were observed in bacterial flora from four or five day specimens. Accompanying this decrease in fibrilar structures, fibrilar structure-mediated aggregation, especially between heterogeneous species of bacteria, remarkably diminished with the exception of aggregation between vesicles on cell walls of gram-negative bacilli and sparse peritrichous fibrils of gram-. negative filamentous bacteria.

The morphological findings of bacteria in human supragingival plaque indicate that bacteria proliferating in the early stage of dental plaque formation colonize by their own fine fibrilar structures, and that the tendency of aggregation in this system decreases in old plaque.

Key words : Freeze-substitution method, Dental plaque, Plaque bacteria, Fibrilar structure, Aggregation

要旨：清掃停止後 1 日から 7 日にわたるヒ卜歯肉縁上プラークを急速凍結置換法によって標本作製し，プラー ク細菌の細胞壁表面から出る微細線維状構造物（線毛）による細菌凝集（線毛性凝集）の様相を電顕的に観察し た。

線毛は分布様式から周毛性線毛（細胞壁全周から出るもの）, 局在性線毛（細胞壁の一部から限局性に出るも 本論文の要旨は, 第 36 回歯科基礎医学会（1994 年 10 月 17 日), 第 102 回岐阜歯科学会（1994 年 12 月 3 日）において 発表した。 
の), 混合性線毛（細胞壁の数カ所から出るもの）に大別され, プラークの各時期に現われた優位菌のほとんど はこのいずれかの型の線毛を有していた。1 日から 3 日のプラークでは, 優位菌のみならずほほ総ての細菌に線 毛を認め，これに伴って corn-cob を含めて同種および異種菌体間で密度の高い線毛性凝集が行われていた。4〜 5 日では菌叢変化に伴って局在性および混合性線毛を有する細菌による同種菌体間凝集に変化し，6〜7 日では, 疎らな周毛性線毛を有するか，線毛を有さない細菌が増加し，線毛を有する細菌では同種菌体間凝集，あるいは 細胞壁表面に小胞を有する細菌との異種菌体間凝集を認めた。

以上の所見は，初期プラークでは線毛性凝集がプラーク中のコロニー形成に深く関わり，古いプラークになる に従って，この傾向が減少することを示すものである。

索引用語：急速凍結置換法, プラーク, プラーク細菌, 微細線維状構造, 凝集

\section{緒言}

口腔疾患の中で最も発症頻度の高いプラーク細菌に よる一連の感染性疾患の病因を解くために, 我々も病 理学の面からプラークを種々検索しつつある。その一 環として，これまでに各プラーク細菌の病原性発揮の 前提となる菌叢変化とこれに伴う増殖の様相, および これらに関わる付着や凝集などについて観察してき た。そして，森 ${ }^{1} は$ は清掃不良状態の歯面から採取した 古いプラーク中の細菌が唾液タンパクが介在する細菌 凝集が顕著であることを, また, 古橋・竹内 ${ }^{2}$ は矯正 治療上，便宜抜歯を計画された歯の清掃停止を依頼す ることによって得た抜去歯歯面のプラークでも，ペリ クル, プラーク基質, およびある種の細菌表面に喠液 タンパクが局在し，それらが付着や凝集に関わってい ることをそれぞれ免疫電顕的に捉えてきた。

さらに永山淿は, 試料の人為的損壊などを可能な限 り避けた状態で, プラーク細菌の経時的な菌叢変化と これに伴って変化するであろう付着や凝集の動態を知 るために, 天然歯表面に装着した carbonate apatite 薄片上のプラークを試料として形態学的および免疫電 顕的観察を行った。その結果, 付着や凝集に唾液夕ン パクが介在するほかに, 細菌が有する微細線維状構造 もこれらに深く関与している可能性を見い出した。し かし，その観察試料は従来の化学固定法によって作製 されたものであるために, 微細線維状構造自体抢よび それらによる付着や凝集の様相を詳細には見きわめ得 なかった。

これら構造物をより詳細に検討するためには, 従来 の化学固定法による電顕観察では不十分であり, 近 年, 細胞の膜構造や微細線維状構造を鮮明に捉えるこ とができ, 細菌の形態的観察にも導入されつつある急 速凍結置換法4 6)を採用するのが最も妥当と考元られ た。

そこで今回，プラーク形成に不可欠な要因の一つで ある凝集に，プラーク細菌の微細線維状構造がどのよ
うに関係しているのかを詳細に観察することを目的と して，清掃停止を依頼した第 1 大臼歯の 1 日から 7 日 にわたるプラークを急速凍結置換法によって標本作製 し，電顕的に観察したので報告する。

\section{研究材料と方法}

\section{1. 研究方法の概略}

まず，プラークに関連すると思われる数種の登録株 について, 急速凍結置換法で得ることができる電顕的 構造を予備的に観察し，以後の参考とした。

次に, 清掃停止後のヒトの歯面から 1 日から 7 日に わたって経時的に採取したプラークを試料として，こ の期間に観察し得た主要細菌の微細線維状構造物（以 下，線毛とする）の形態の分類，およびこれらによる 菌体間凝集（以下，線毛性凝集とする）の様相を検討 した。

\section{2. 観察試料の採取}

1）登録株の培養と採取

表 1 に示すStreptococcus, Actinomyces, Fusobacterium, Porphyromonas, Prevotella の 5 種 株を選んだ。

各菌は $0.5 \%$ 酵母エキス（Difco, U.S.A.）添加 Tripticase soy broth (B.B.L., Cackeysvill, U.S.A.) あるいは $\mathrm{CDC}$ 処方嫌気性菌用羊血液寒天培地（B.B. L., Nippon Becton Dickinson，東京）で 24 時間培養 し, 一旦, 生食浮遊液とした後に緩やかに遠心 (2,000 rpm/5 分) し，沈渣を試料として採取した。

2）プラーク細菌の採取

全身的に異常がなく，また蠆蝕や歯周炎に罹患して いない $20 \sim 24$ 歳の本学学生 22 名（ア12 名, ㅇ 10 名）に了解を得て，スケーリングとブラッシングで歯 面を徹底的に清掃した後，両側の上下顎第 1 大臼歯付 近の清掃を 7 日間停止させた。

そして，1日から 7 日にわたって各日にスプーンエ キスカベーターによって歯肉緑上プラークを採取し, 生食に浮遊，遠心 $(2,000 \mathrm{rpm} / 5$ 分）し，沈渣を試料 
表 1 観察に供した登録株とその培地および培養条件

\begin{tabular}{|c|c|c|}
\hline strain & medium & incubate condition \\
\hline \multicolumn{3}{|l|}{ Streptococcus } \\
\hline $\begin{array}{l}\text { sanguis ATCC } 10556 \\
\text { mutans ATCC } 25175 \\
\text { salivarius ATCC } 25975\end{array}$ & $\begin{array}{l}1.5 \% \text { Tripricase soy agar } \\
\text { containing } 0.5 \% \text { Yeast Extract }\end{array}$ & anaerobic, $37^{\circ} \mathrm{C}$ for 24 th \\
\hline $\begin{array}{l}\text { Actinomyces } \\
\text { viscous ATCC } 19246\end{array}$ & $\begin{array}{l}1.5 \% \text { Tripricase soy agar } \\
\text { containing } 0.5 \% \text { Yeast Extract }\end{array}$ & anaerobic, $37^{\circ} \mathrm{C}$ for 24 th \\
\hline $\begin{array}{l}\text { Fusobacterium } \\
\quad \text { nucleatum BN } 11 \mathrm{a}-\mathrm{d}\end{array}$ & CDC anaerobe blood agar* & anaerobic, $37^{\circ} \mathrm{C}$ for 24 th \\
\hline $\begin{array}{l}\text { Porphyromonas } \\
\text { gingivalis } 381\end{array}$ & CDC anaerobe blood agar* & anaerobic, $37^{\circ} \mathrm{C}$ for 24 th \\
\hline $\begin{array}{l}\text { Prevotella } \\
\quad \text { intermedia ATCC } 25611\end{array}$ & $\mathrm{CDC}$ anaerobe blood agar* & anaerobic, $37^{\circ} \mathrm{C}$ for 24 th \\
\hline
\end{tabular}

*prepared by Center for Disease Control

とした。

\section{3. 急速凍結置換法}

ペレット状の登録供試菌，およびプラークをそれぞ れ $1 \mathrm{~mm}^{3}$ 大に調製し，冷却コンテナ内に入れ凍結固 定した。なお，コンテナは液体チッソで冷却（一 $\left.196^{\circ} \mathrm{C}\right)$ し，そこにプロパンガスを静かに注入し，適 量の液化プロパンを冷媒とした。

凍結固定した試料は， $-80^{\circ} \mathrm{C}$ に冷却したアセトン 液に四酸化オスミウム（キシダ化学，大阪）を 3 $4 \%$ 溶かし込んだ置換液に移し， $-80^{\circ} \mathrm{C} て ゙ 24$ 時間保 存した。次にこれを室温まで徐々に戻し，試料を純ア セトンで 2〜3 回濯ぐことによって凍結置換を行った。 なお，凍結置換液には，水分を除くため夕イプAモレ キュラーシーブ（ナカライテスク，京都）を用いた。

\section{4. 電顕観察試料の作製と観察方法}

凍結置換した試料を包埋用シリコン平板にてエポン 812 レジンキット（TAAB, England）で包埋し， $60^{\circ} \mathrm{C}$ で 2 日間重合した後, 包埋試料からガラスナイ フで約 $1 \mu \mathrm{m}$ の標準切片を作成した。これを $1 \%$ トル イジンブルーで染色し, 光学顕微鏡（ニコンバイオ フォト，東京）にて試料中の細菌の存在の確認を行っ た後, 約 $70 \mathrm{~nm}$ の超薄切片を作製し（ダイヤモンド ナイフ；DIATOME，日新 EM，東京，ミクロトー ム ; EM-super nova, Reichert-Jung, Austria), 1\% 酢酸ウランを室温で 5 分， $0.1 \%$ クエン酸鉛 $0.1 \mathrm{~N}$ 水 酸化ナトリウム溶液で 1 分間の電子染色を行い, JEM - $1200 \mathrm{EX}$ (日本電子, 東京), および H 7100 (日立, 東京) を用いて電子顕微鏡的観察を行っ た。
なお，今回の凍結固定では，試料の表層より 5〜10 $\mu \mathrm{m}$ までの領域で良好な固定状態が得られ，それより 深層では種々の程度の水晶形成による細菌形態の破壊 が認められたため, 観察はすべて表層 5〜10 $\mu \mathrm{m}$ まで の領域に限定した。

\section{研究結果}

\section{1. 各登録株の線毛形態}

培養後に採取した各菌株は, 急速凍結置換による電 顕観察で次のような構造を示した。

1) Streptococcus

今回供試されたStreptococcus は, いずれも電子密 度の高い無構造の細胞壁を有し, ここから全周にわ たって出る均一な線毛を認めた。線毛の長さは $S$. sanguis と $S$. mutans は約 $40 \mathrm{~nm}$ (図 $1 \mathrm{~A}, \mathrm{~B}$ ), $S$. salivarius は約 $80 \mathrm{~nm}$ であった（図 $1 \mathrm{C)。}$

2) Actinomyces

やや電子密度の低い細胞壁を有し, この全周から出 る長さ密度とも不規則な線毛を認めた。なお, 密な線 毛部では互いの線毛が絡んで網目構造をとっていた (図 1 D)。

\section{3) Fusobacterium}

細胞壁はやや電子密度が低く薄い層をなし，これを 被う外膜の全周にわたって, 疎らで不規則な長さの線 毛を認めた（図 $1 \mathrm{E}$ )。

4) Porphyromonas

外膜は電子密度が高く, 線毛はその外膜の全周から 出ており,その長さは約 $30 \mathrm{~nm}$ で均一であった（図 1 

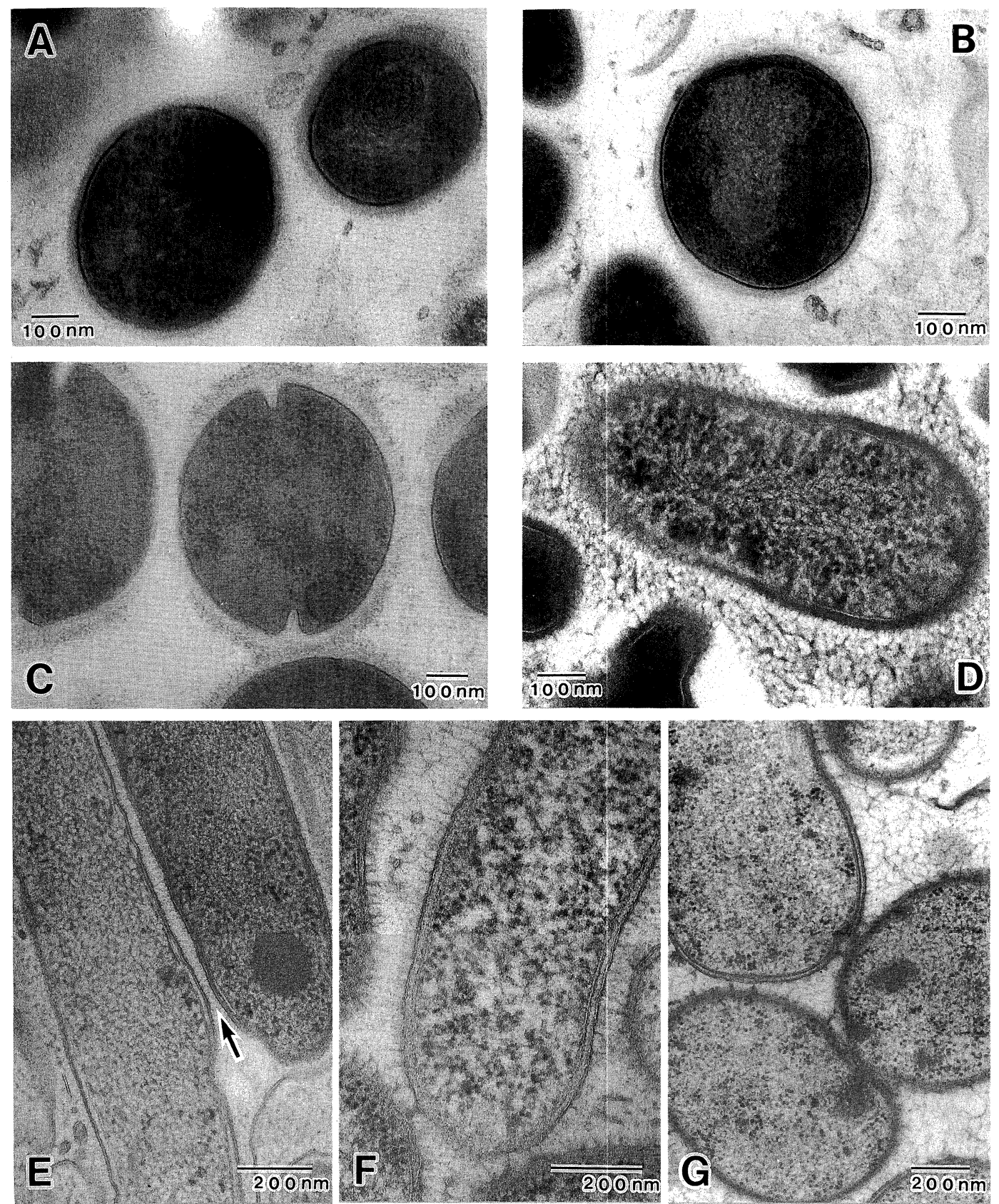

図 1 各登録株の線毛形態
A. Streptococcus sanguis ATCC 10556
E. Fusobacterium nucleatum BN 11 a-d
B. S. mutans ATCC 25175
( $\rightarrow$ は線毛を示す)
C. S. salivarius ATCC 25975
F. Porphyromonas gingivalis 381
D. Actinomyces viscosus ATCC 19246
G. Prevotella intermedia ATCC 25611

F)。

\section{5) Prevotella}

電子密度が高く明瞭な細胞壁を有し，その表層全面 から出る短く, やや疎らな線毛を認めた（図 $1 \mathrm{G}$ )。
以上のように，今回観察した菌株のすべてに線毛を 認めることができた。また, それらの電顕的構造を従 来の化学固定による所見と比較検討してみると,いず れの菌も, 細胞壁などの膜構造がはるかに明瞭であ 

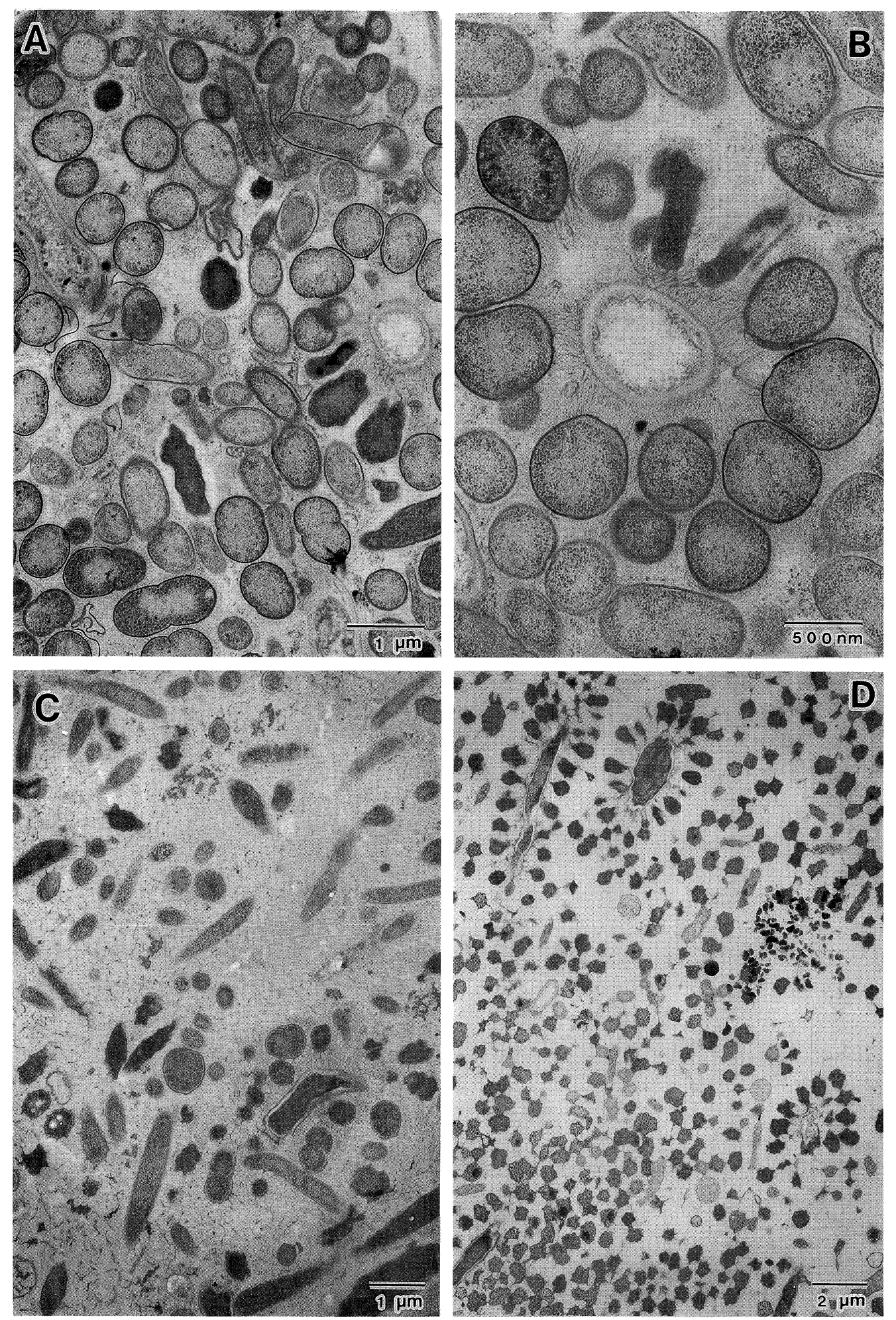

図 2 プラーク細菌の経時的変化
A. 清掃停止後 3 日目のプラーク細菌
C. 5 日目のプラーク細菌
B. 3 日目プラーク中の corn-cob
D. 7 日目のプラーク細菌 


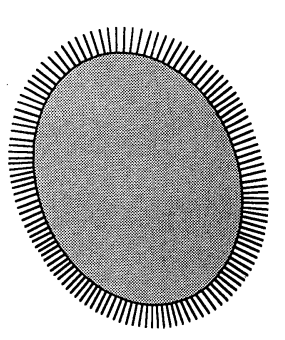

A

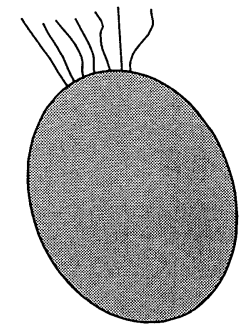

B

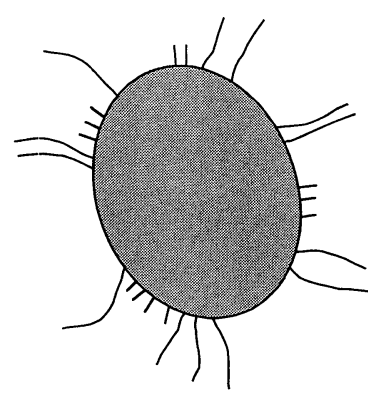

C

図 3 プラーク細菌の線毛形態の分類の模式図

A. 周毛性線毛 B. 局在性線毛 C. 混合性線毛

り, とくに線毛形態は化学固定では得られない微細で 詳細な構造として認めることができた。

2. プラーク細菌の線毛形態と炎の線毛による凝集 の観察結果

まず，歯面清掃停止後 $1 \sim 7$ 日間のプラーク細菌の 動態を形態的に観察してみると，すでに多くの報告に みられる通り経時的に種々の菌相変化を示した。これ を概略的にみると，歯面清掃停止後 3 日頃まではグラ 么陽性球菌と同桿菌が優位菌の位置を占め（図 2 A)，2〜3 日ではプラーク表面に corn-cobを認めた (図 2 B)。4 ないし 5 日頃には, これら優位菌が急速 に減少し，新たに分ラム陰性菌群および線状菌が現れ (図 2 C), 6〜7 日では, ひき続いてこれら細菌の増殖 を認めた（図 2 D)。

1) プラーク細菌の線毛形態

この全期間を通して認められた細菌の線毛形態を通 覧してみると, 線毛は細胞壁の全周にわたって認めら れるもの (以下, 周毛性線毛とする), 細胞壁の一部 にのみ存在するもの (以下, 局在性線毛とする), お よび周毛性と局在性線毛の中間的な存在様式を示すも の，すなわち細胞壁に不連続的に認めるもの（以下， 混合性線毛とする）の 3 種に大別できた（図 3)。

2) 菌種別にみた線毛形態

これを球菌, 桿菌, 線状菌の形態的分類に基づいて みると以下のごとくであった。

(1) 球菌の線毛形態

観察の全期間を通して認めた球菌は，グラム陽性お よび陰性菌ともすべて周毛性, 局在性, 混合性のいず れかの線毛を有していた。

周毛性を有する球菌では, 約 $40 \mathrm{~nm}$ の均一で密な もの (図 $4 \mathrm{~A}$ ), 約 40〜80 nm の不規則な長さの線毛 が密なもの (図 $4 \mathrm{~B}$ ), および約 100〜120 nm で疎ら なもの（図 4 C) が主であった。
局在性線毛を有する球菌では, 電子密度が低く途中 で交織し網目状構造をなすものが一種類, また, 混合 性線毛を有する球菌も一種類のみで, 約 $80 〜 400 \mathrm{~nm}$ の異なる長さの線毛を細胞壁から不連続性に出て途中 で分枝していた（図 4 D)。

(2) 桿菌の線毛形態

周毛性線毛を有する菌 4 種, および局在性線毛を有 する菌, 混合性線毛を有する菌各 1 種類を認めた。

周毛性線毛を有する菌では, 均一の長さの線毛を有 する菌と長さの異なる線毛を有する菌とがあり, 前者 には，約 $10 \mathrm{~nm}$ および $40 \mathrm{~nm}$ の密生した線毛を有す る菌 2 種 (図 $5 \mathrm{~A}$ ), 後者に山約 40〜120 nm および 40〜200 nm の疎らな線毛を有する菌 2 種があった (図 5 B)。

局在性線毛を有するものでは, 電子密度の低い線毛 が交織し網目構造を形成していた（図 5 C)。

また，混合性線毛を有する菌では，その線毛は外膜 の数力所より約 $150 \mathrm{~nm}$ および $200 〜 400 \mathrm{~nm}$ の異なる 長さで出ていた（図 5 D)。

(3) 線状菌の線毛形態

線状菌の線毛は全般的に豊富ではなく, 中にはこれ を全く認めない菌もあった。優位菌の中で線毛を有し た菌では, 疎らで短い周毛性線毛あるいは疎らで不規 則な長さの周毛性線毛を有していた（図 6)。

3）優位な菌の線毛形態

次に以上の中から, 清掃停止後 1 日から 7 日間にわ たる間の菌相変化の各時期において, 優位な菌として 認めた細菌の線毛形態を観察すると以下のようであっ た。

1 日から 3 日の間では, 優位な菌である球菌および 桿菌とも豊富な周毛性線毛を有し, とくに約 $40 \mathrm{~nm}$ の均一な長さの周毛性線毛を密に有する球菌が主体を 占めた (図 $7 \mathrm{~A})$ 。 

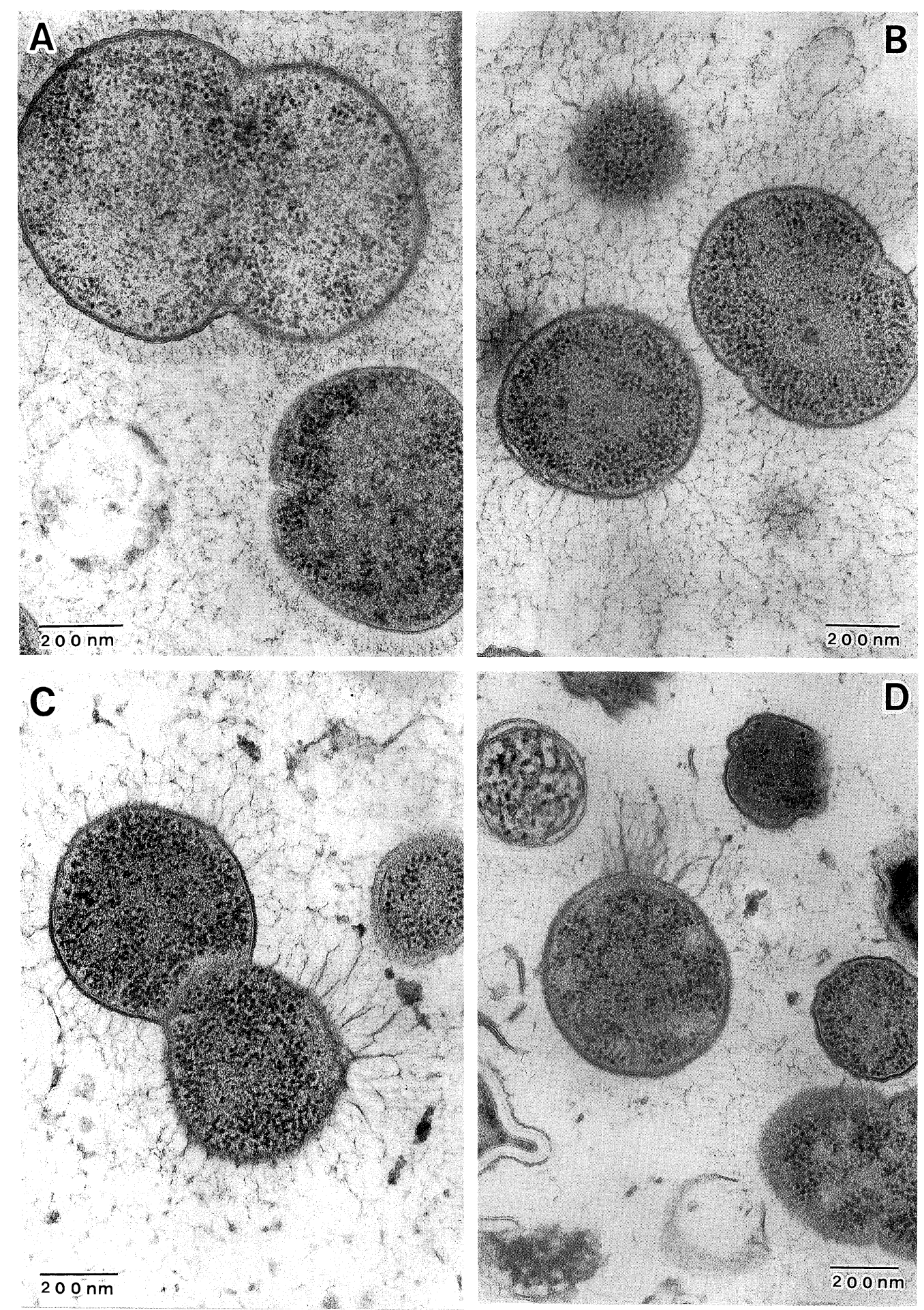

図 4 プラーク中の球菌の線毛形態
A. 均一な長さの周毛性線毛を有する球菌
C. 疎らな周毛性線毛を有する球菌
B. 不規則な長さの周毛性線毛を有する球菌
D，混合性線毛を有する球菌 

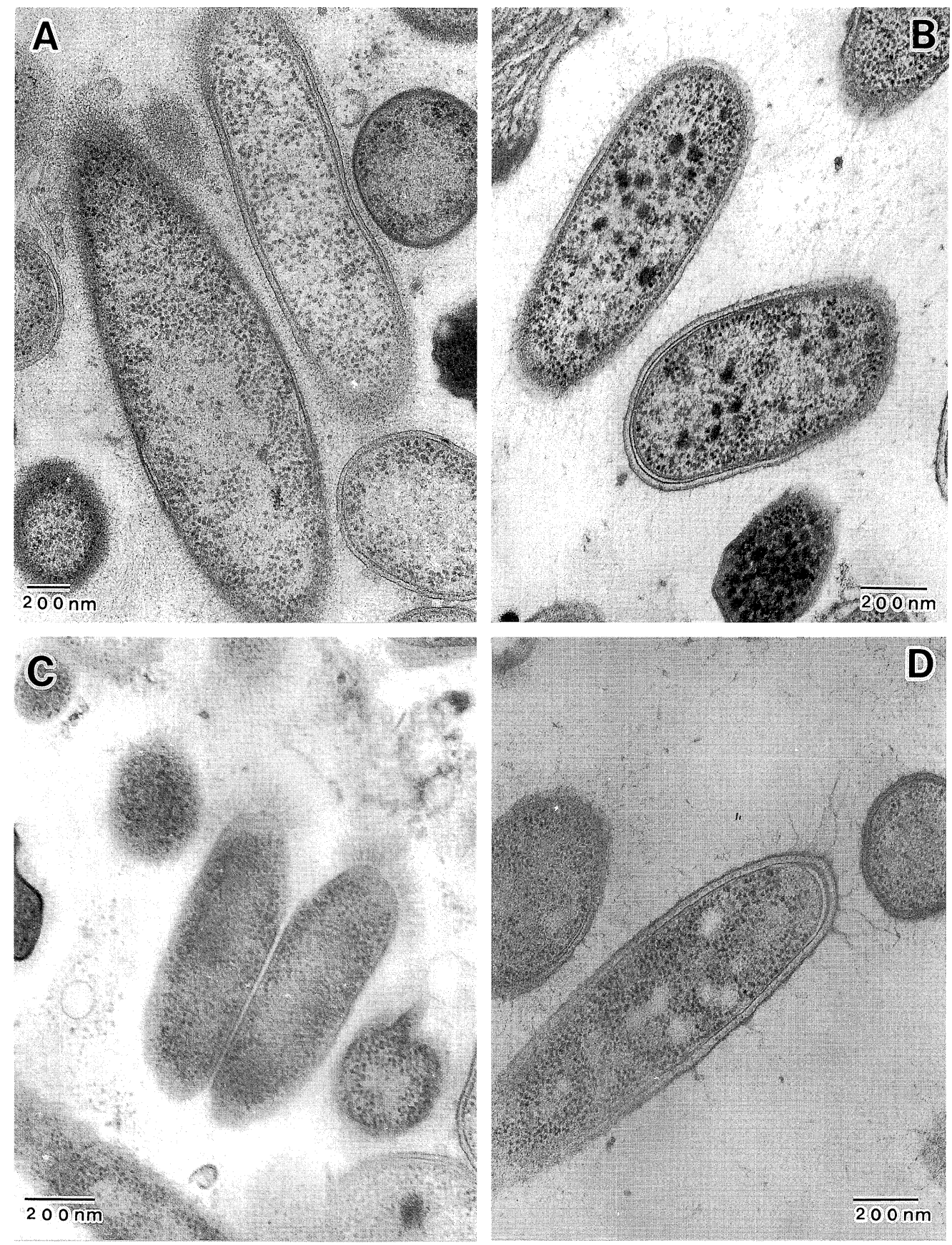

図 5 プラーク中の桿菌の線毛形態
A. 均一な長さの周毛性線毛を有する桿菌
C. 局在性線毛を有する桿菌
B．疎らな周毛性線毛を有する桿菌
D. 混合性線毛を有する桿菌

4 ないし 5 日の著しい菌叢変化期には，局在性線毛 および混合性線毛を持つ球菌および桿菌が最も多く認 められた（図7 B)。

一方，それ以降は疎らな周毛性線毛のグラム陽性線 状菌が優位を占め，また，線毛とは関係ないが，外膜
に小胞状構造を有するグラム陰性短桿菌も比較的多く 認めた（図 7 C)。

4）線毛性菌体間凝集の観察

以上のような線毛を有する細菌は, その線毛を介し て同種菌体間をつなぎ，また同時に異種菌体間とも連 


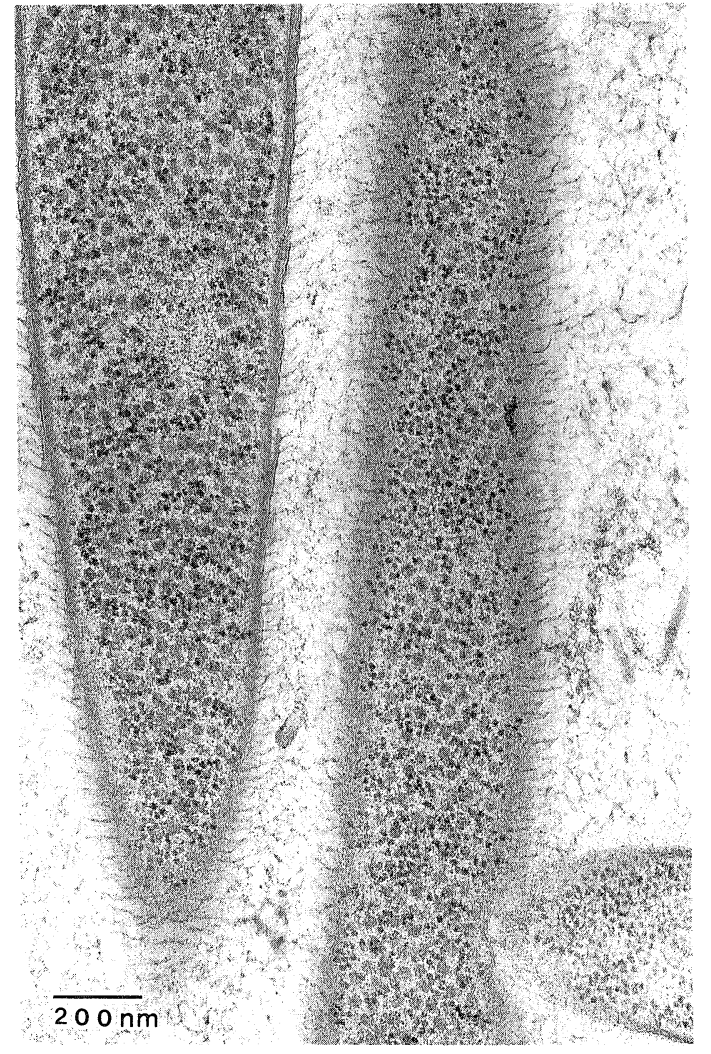

図 6 プラーク中の線状菌の線毛形態

絡していた。そしてこの線毛性菌体間凝集には，プ ラーク細菌の経時変化に対応して各時期に次のような 特徴を示した。

（1）清掃停止後 1 3 日の線毛性凝集

この時期には線毛を有する球菌や桿菌を中心とする 種々の細菌が増殖し，線毛はプラーク全体を錯走する 観を呈したが，これ伴って線毛性凝集も複雑多岐の 様相を呈した。

これをまず線毛性同種菌体間凝集についてみると, 球菌および短桿菌は長さが均一で短い周毛性線毛，ま たは均一で長い周毛性線毛で連なっているものが最も よくみられ，桿菌では短く疎らな周毛性線毛で連絡し ていた（図 $8 \mathrm{~A} ， \mathrm{~B}$ )。

一方，異種菌体間凝集は球菌間抢よび球菌と桿菌の 間に最も多くみられ，そのほとんどは互いの周毛性線 毛で連なっていた（図 8C，D）が，中でも2〜3 日頃 に現れた corn-cob の異種菌体間凝集は極めて特徵的 であった。corn-cobの軸をなす菌のほとんどは電子 密度が低く透明に近い幅広い細胞壁と,やはり電子密 度の低い外膜を有する線状菌で，一部にこれとは異な る形態を示す細菌があった。その周囲菌は電子密度の 高い細胞壁を有する球菌が主であったが，これ以外の
細菌も corn-cob の周囲菌として認められた。そして 軸菌からは電子密度が高く微細で短い周毛性線毛が出 て，周囲菌の局在性線毛あるいは混合性線毛と連なっ ていた。な扔，周囲菌の間隙は狭く，同部は短い混合 性線毛によって凝集していた (図 2 B)。

（2）清掃停止後 4〜5日の線毛性凝集

この時期では，主として局在性線毛や混合性線毛を 持つ球菌および桿菌，さらに疎らで短い周毛性線毛を 持つ線状菌が認められたが，それら線毛の多くはプ ラーク基質に終わり (図 7 B), 線毛性凝集は混合性 線毛を有する同種菌体間でみられるのみで（図 8 E), この中の一部には, 異種菌や崩壞した細菌の残 留物と思われる物質と連なるものもあった。

(3) 清掃停止後 6〜 7 日の線毛性凝集

この時期では疎らな線毛を有する細菌がほとんどで あり，これに伴って線毛性凝集は形態的にみて単純な 様相を呈することが特徴であった。その多くは疎らな 周毛性線毛による同種菌体間凝集に停まり(図 8 F), 異種菌体間凝集は混合性線毛を介するグラム陽 性球菌と同陰性球菌との間で認められたにすぎなかっ た。しかし，異種菌体間凝集の一型とみなし得るもの として, 線状菌の短い周毛性線毛とグラム陰性球菌か 同桿菌が有する外膜上の小胞状構造物との結合が数多 く認められた（図 $8 \mathrm{G}$ )。

また，この時期には線毛性凝集を行わずにプラーク 基質中に孤立した状態で存在する細菌を最も多く認め たものも特徵の 1 つであった (図 $8 \mathrm{H}$ )。

なお，全期間を通じて，線毛による菌体間凝集を行 いつつある細菌に打いて，その凝集に関わらない部分 は遊離端となってプラーク基質中に終わっていた。

\section{考 察}

周知のように，プラーク細菌が歯面に定着・増殖す るうえにおいて付着と凝集は必須条件になる7 ${ }^{7-9)}$ 。付 着は唾液タンパクが形成するペリクルを介して，また 凝集は細菌の直接的結合や唾液夕ンパク介在による間 接的結合で生じる。そしてこれらが歯面に口腔細菌を 固着させ，同時にコロニー形成を支持する。このよう な細菌付着や凝集には細菌表面の種々の構造物が関与 しているが，これらの構造物の中でも，近年とくに細 胞壁表面から出る微細線維状構造が注目されつつあ $る^{10 \sim 13)}$ 。しかし, 細胞壁から出る微細線維は, 従来 の化学固定で作製した薄切切片では詳細に捉えること は極めて困難であり, 従って, この構造物による付着 や凝集の様相は十分に知られていない。今回，この点 を克服するために急速凍結置換法で作製したプラーク 

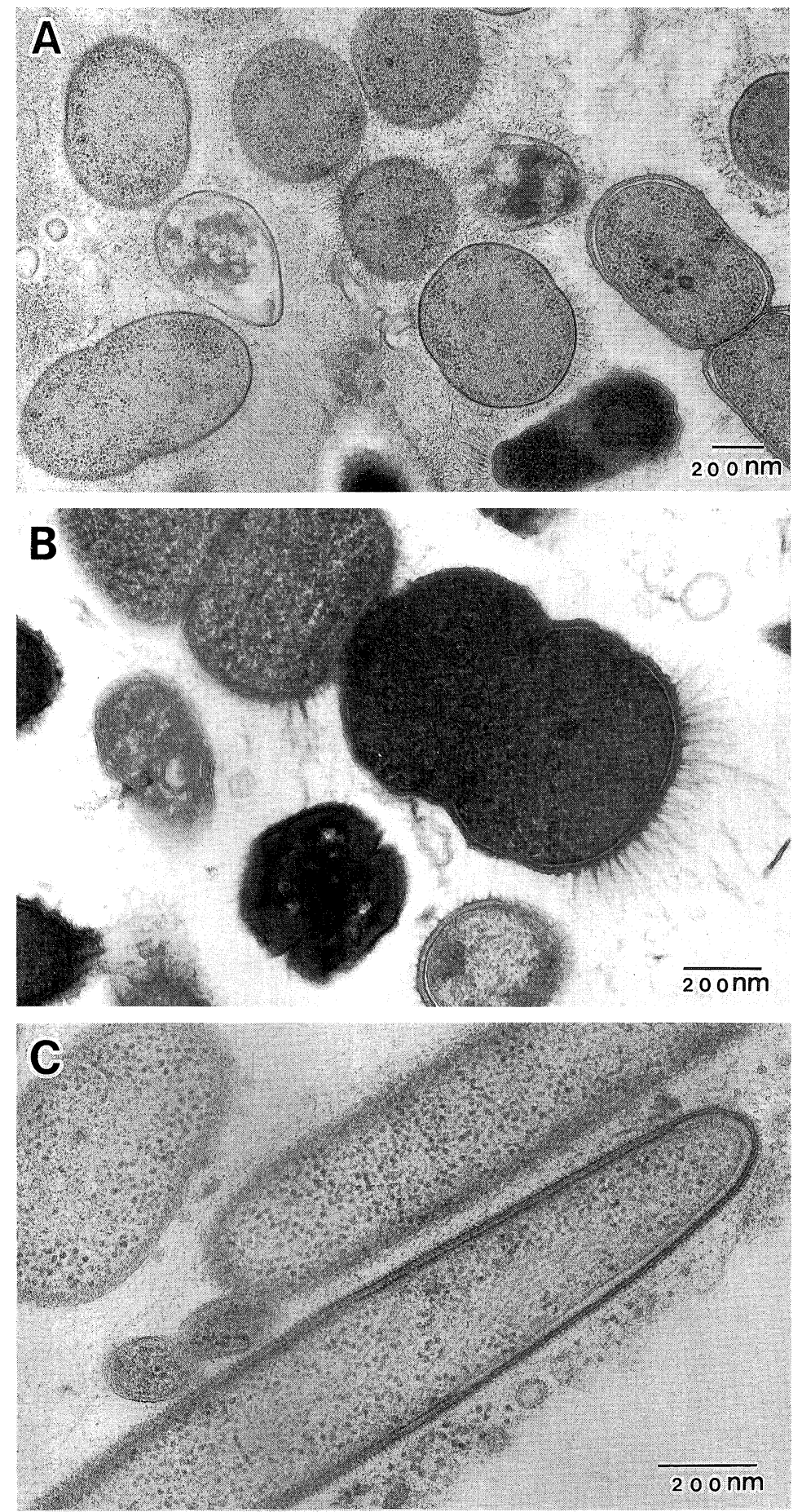

図 7 清掃停止後 1 日から 7 日の期間に現れた優位な菌の線毛形態

A. 1 日から 3 日の優位な菌（球菌および桿菌）の周毛性線毛

B. 4 日から 5 日の優位な菌（球菌）の混合性線毛

C. 6 日から 7 日の優位な菌（線状菌）の疎らな周毛性線毛 

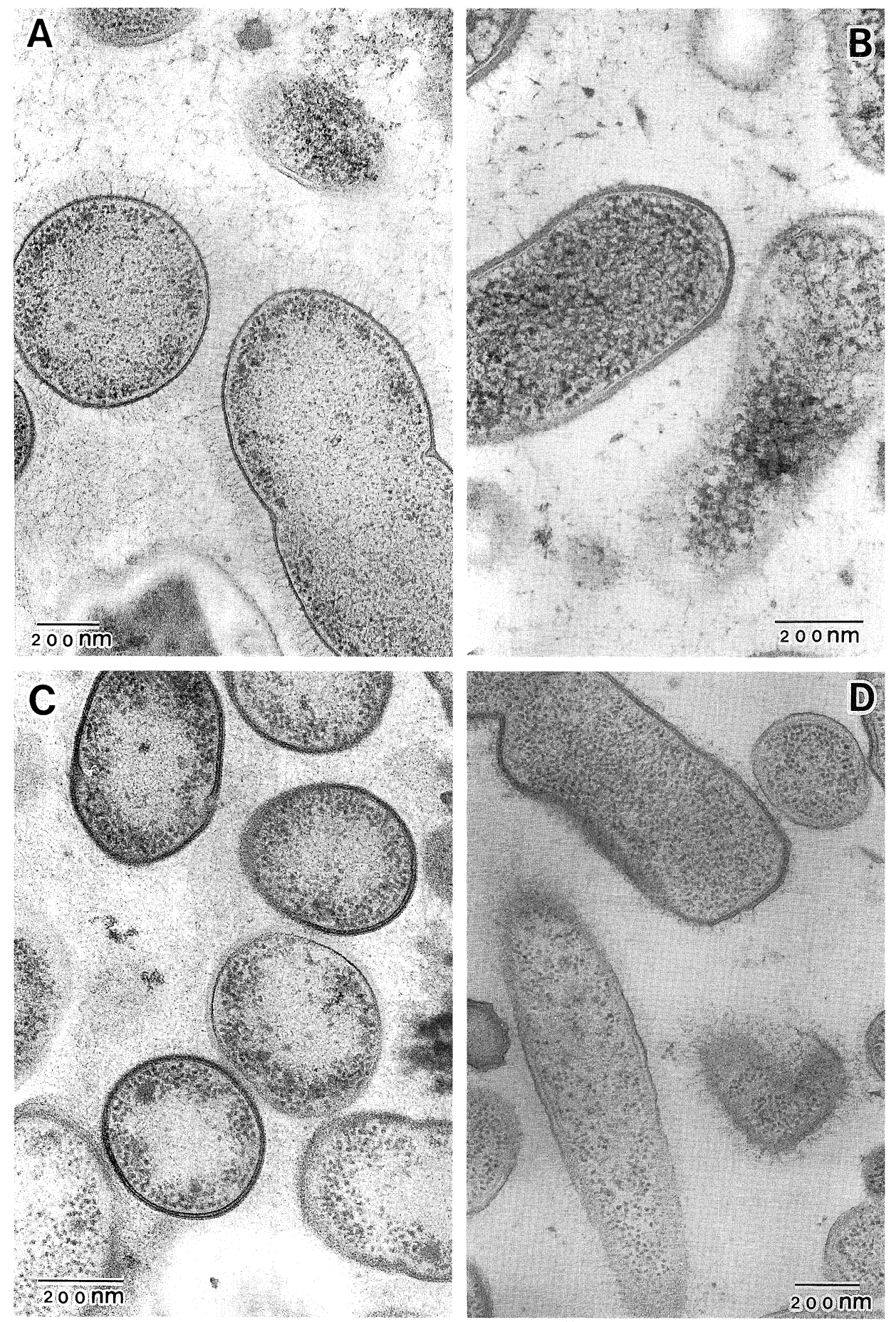

図 8 経時的にみた線毛性凝集の推移

A. 1 日から 3 日の球菌の周毛性線毛性同種菌体間凝集

B. 1 日加ら 3 日の桿菌の周毛性線毛性同種菌体間凝集

C. 1 日加 3 日の球菌の周毛性線毛性異種菌体間凝集

D, 1 日から 3 日の桿菌と球菌の周毛性線毛性異種菌体間凝集 

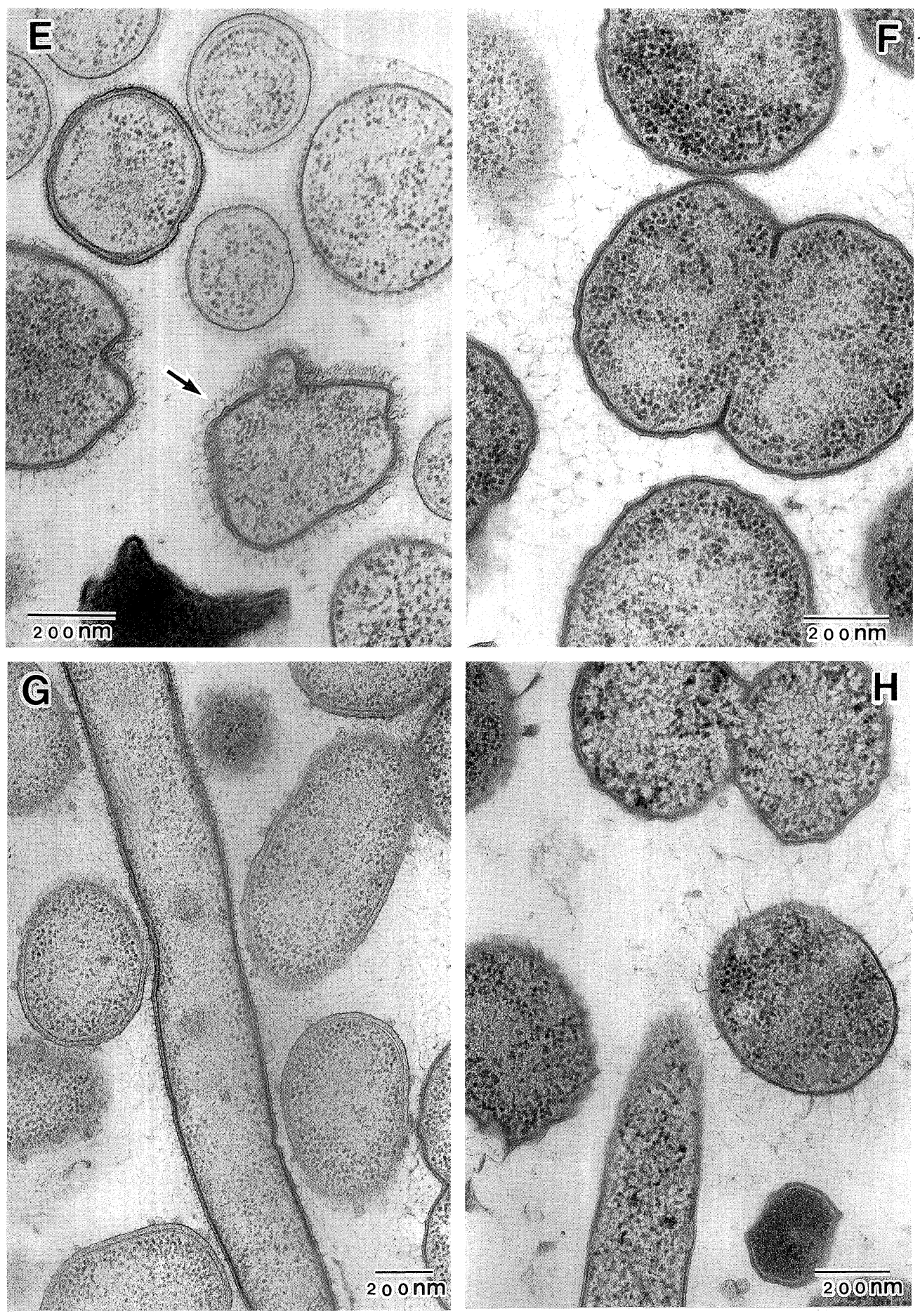

E．4日から 5 日の球菌の線毛性同種菌体間凝集とプラーク基質饭終わる線毛 $(\rightarrow)$

F。6 日加ら 7 日の球菌の踈らな周毛性線毛性同種菌体間凝集

G. 6 日から 7 日の線状菌の周毛性線毛と桿菌の小胞との異種菌体間凝集

H. 6日から 7 日のプラーク基質に終わる球菌の線毛 
試料を電顕的に観察したが, 観察に先立って, まず培 養した登録株について化学固定との差異を検討した。 その結果, 各細菌の膜構造および微細線維状構造が従 来より飛躍的に鮮明であることが確認し得た。また， とくに微細線維状構造については, negative staining によって呈示された Handley ら ${ }^{14)} の$ 所見などとも比 較し，その形態の概要は本質的には同じであるもの の, 細部にわたる観察については凍結置換法が negative staining をはるかに凌ぐものであることも併せて 判明した。

なお, これら細胞壁から出る線維状構造物は pili, fimbriae, fibril などの名称が与えられ区別されてい るが, 我々はそれぞれの正確な判別をなし得なかった ため, これらをすべて線毛，またその凝集を線毛性凝 集の仮称でまとめた。

線毛形態は, 今回観察した清掃停止後 1 日から 7 日 の期間に現れた菌種によって様々であったが，その分 布様式によって周毛性線毛, 局在性線毛および混合性 線毛に大別し得た。そして，これら線毛形態およびこ れに伴う線毛性凝集は，この期間にみられた菌叢変化 に相関して特徴を認めることができた。その菌叢変化 は, 天然歯表面に装着した carbonate apatite 薄片上 のプラークで，第 1 期（1〜3 日), 第 2 期（4〜 5 日） および第 3 期 (6 日以降) に分類した永山 ${ }^{3)}$ の所見と 全く同一であったが，第 1 期の優位な菌のほとんどは 豊富な線毛を有し，第 2 期の優位な菌は局在性および 混合性線毛を有するものに変化し，さらに第 3 期では 線毛を有する菌が著しく減少した。このような菌叢変 化に伴う線毛の量的・質的変化は, 単に菌種間の性状 の相違によるだけでなく，その生息条件にも関係があ ると考えられる。例えば, プラーク中の環境的要因に 左右されることによる線毛の形成の程度の差異や, 形 成された線毛のプラーク中の酵素などによる破壊など である。

次にこれら線毛による線毛性凝集についてみると, 細菌間を連絡し菌体間凝集に関わるものと, プラーク 基質に終わり基質との凝集に関わるものとに大別でき たが, 第 1 期では約 $40 \mathrm{~nm}$ や. 40〜80 nm の長さの周 毛性線毛を持つ 2 種類の球菌, および不規則な長さの 線毛を有する桿菌が中心となって同種菌体間および異 種菌体間凝集を行い，第 2 期では局在性および混合性 線毛を持つ球菌や桿菌の同種菌体間凝集, 第 3 期では 疎らで短い線毛による同種菌体間凝集および小胞状構 造物を介した球菌や桿菌との異種菌体間凝集が特徴的 であった。

今回のような形態的観察のみでは, 各時期の細菌種 の同定は不可能であったが, これまでの先人達の検索
をみると, 第 1 期の優位な菌はStreptococci, Actinomyces, Nocardia, Neisseria どであ る $^{9,10,15,16)}$ が，この中でとくにS. sanguis，S. mitis お よび A. viscosus は優位な菌であると同時に, ペリク ルに選択的付着性を示し, プラーク形成の出発細菌で あることが明らかにされている17 19)。さらにS. sanguis は線毛にレクチン様付着子を持ち20,21), ペリクル 中の唾液タンパクと特異的に結合すること祖,23), ま た, 同菌には 2 種類の線毛を有する菌種があり, 局在 性線毛を持つ細菌よりも周毛性線毛を持つほうが唾液 処理ハイドロキシアパタイトに高い付着性を示すこ と ${ }^{10,22)}$ が知られている。A. viscosus や A. naeslundii では, type 1 fimbriae がペリクルと結合し ${ }^{12,13)}$, ペリ クル中の prolin-rich protein と反応すること ${ }^{12)}$ およ びその付着性は線毛密度依存性であることが知られて いる。これら細菌は単にペリクルに選択的付着性を示 すのみならず，さらに線毛性菌体間凝集を行っている ことは今回の観察で明らかである。因みに, 異種菌体 間凝集では, S. sanguis は A. viscosus, Fusobacterium nucleatum おょ びPorphyromonas gingivalis $^{14,24,29)}$ と, S. salivarius は Veillonella ${ }^{11)}$ と, P. gingivalis は $S$. sanguis 以外にEubacterium や Capnocytophaga ${ }^{25)}$, あるいはA. viscosus やF. nucleatum $^{26,27)}$ と結合することが明らかにされている が，このように菌種が特定されている点を考えれば, 異種菌体間凝集には特異性がある可能性が高い。独特 の異種菌体間凝集である corn-cobも同様に菌種特異 性があるようで, Takazoe ら ${ }^{28)}$ は Corynebacterium matruchotii と S. sanguis との間で，また Lancy ら ${ }^{29)}$ はF. nucleatum と S. sanguis との間で形成されると みなしている。本観察では, corn-cobの軸菌は電子 密度が低く幅広い細胞壁を有するものがほとんどで, 極く一部にこれと異なるものを認め, 周囲菌はグラム 陽性菌が主であったが，やはり一部に短桿菌のような 異種菌が混じており，しかも軸菌の周毛性線毛と周囲 菌の局在性ないし混合性線毛とが連なり,さらに周囲 菌間は混合性線毛の一部で凝集していた。この線毛性 凝集をみる限りにおいて, corn-cobでは細菌間がか なり強固に凝集していることが窅われた。

第 2 期はいわば菌叢変化期とみなし得る時期で, 第 1 期のグラム陽性菌群の崩壊に伴ってその線毛も消失 し，これに代って優位な菌となった細菌の線毛は局在 性あるいは混合性線毛を有し, 主に同種菌体間凝集 や，プラーク基質に終わって基質との凝集に関わり， 線毛による異種菌体間凝集はほとんど行われないとい う特徵を示した。

第 3 期では線毛を有する細菌が著しく減少し，これ 
を有する細菌でも菌体間凝集を行うものは少なくむ しろ第 2 期でみられたようにプラーク基質に終わるも のがさらに多くみられるようになった。ただ，例外的 にこの時期には特異的な線毛性凝集を認めた。これは 長桿菌の有する踈らで短い線毛と短桿菌の細胞壁表面 の小胞との結合であり，この点に関して，Grenier and Mayrand ${ }^{25)}$ は小胞を有する細菌は P. gingivalis で，これを介して結合する細菌はEubacteriumや Capnocytophagaであるとし, Ellen and Grove ${ }^{26)}$ A. viscosus であることを見い出している。

以上の所見は，第 1 期では線毛性菌体間凝集が同種 および異種細菌間で密度高く行われるのに対して，グ ラム陰性細菌への菌叢変化期以降，この線毛性菌体間 凝集が減少し，プラーク基質との凝集に移行して行く ことを示している。Watanabe ${ }^{30)}$ はこのような線毛性 凝集性あるいは付着性は線毛密度依存性であることを 指摘している。この点を考え併わせると，第 1 期の付 着と凝集は極めて強固であるとみなすことができる。 また，今回の急速凍結置換法による観察では，優位な 菌のほとんどは，何らかの形で線毛を有することが明 らかになり，ひいてはこれまでに予測されてきた以上 に線毛による凝集が多くのプラーク細菌間，あるいは プラーク基質との間で行われていることが窅えた。

なお，線毛による凝集の機序については，線毛のい ずれかの部位に存在する，いわゆる接着分子が関与し ていることが考えられるが，この点については現在検 索中であり，結果を得て報告する計画である。

\section{文献}

1）森 哲彦：ヒトの歯垢における fibronectin の局在 性について。岐歯学誌, $18 ： 263-281,1991$.

2）古橋 達，竹内 宏：プラーク形成過程とその過程 に扔ける唾液タンパクの局在. 日歯周誌, $36 ： 305-$ 323, 1994

3）永山元彦：Carbonate apatite片上に形成されたプ ラーク細菌の付着と凝集. 岐歯学誌，25：1998.（投 稿中)

4) Graham, L.L. and Beveridge, T.J. : Evaluation of freeze-substitution and conventional embedding protocols for routine electron microscopic processing of eubacteria. J. Bacteriol., $172: 2141-2149$, 1990.

5) Paul, T.R. and Beveridge, T.J. : Reevaluation of envelope profiles and cytoplasmic ultrastructure of mycobacteria processed by conventional embedding and freeze-substitution protocols., J. Bacteriol., 174：6508-6517, 1992.
6) Graham, L.L. : Freeze-substitution studies of bacteria. Electron Microsc. Rev., 5: 77-103, 1992.

7) Theilade, J. : Dental plaque and dental calculus, Lindhe, J., Textbook of Clinical Periodontology, Munksgaard, Copenhagen, 1984, 85-124.

8) Sanz, M. and Newman, M.G. : Dental plaque and calculus, Newman, M.G. and Nisengard, R., Oral Microbiology and Immunology, Saunders, Philadelphia, 1988, 367-388.

9) Schonfeld, S.E. : Oral Microbial Ecology, Slots, J. and Taubman, M.A., Contemporary Oral Microbiology and Immunology, Mosby-Year Book, St. Louis, 1992, 267-274.

10) Wyatt, J.E. and Handley, P.S. : Aggregation of Streptococcus sanguis biotypes I and II by parotid saliva : a comparison between peritrichously fibrillar and tufted strains. Microbios., $51: 113$ $-123,1987$.

11) Handley, P.S., Harty, D.W.S., Wyatt, J.E., Brown, C.R., Doran, J.P. and Gibbs, A.C.C. : A comparison of the adhesion, coaggregation and cellsurface hydrophobicity properties of fibrillar and fimbriate strains of Streptococcus salivarius. J. Gen. Microbiol., 133 : 3207-3217, 1987.

12） Clark, W.B., Beem, J.E., Nesbitt, W.E., Cisar, J.O., Tseng, C.C. and Levine, M.J. : Pellicle receptors for Actinomyces viscosus type 1 fimbriae in vitro. Infect. Immun., 57 : 3003-3008, 1989.

13) Amano, A., Sojar, H.T., Lee, J.-Y., Sharma, A., Levine, M.J. and Genco, R.J. : Salivary receptors for recombinant fimbrillin of Porphyromonas gingivalis. Infect. Immun., 62 : 3372-3380, 1994.

14) Handley, P.S., Carter, P.L., Wyatt, J.E. and Hesketh, L.M. : Surface structures (peritrichous fibrils and tufts of fibrils) found on Streptococcus sanguis strains may be related to their ability to coaggregate with other oral genera. Infect. Immun., $47: 217-227,1985$.

15) Ritz, H.L. : Microbial population shifts in developing human dental plaque. Archs. Oral Biol., 12:1561-1568, 1967.

16）奥田克爾：歯周病原性細菌の定着機序，医学細菌学 1 巻, 中野昌康, 吉川昌之介, 竹田美文, 菜根出 版，東京, 1986, 133-160。

17) Cowan, M.M., Taylor, K.G. and Doyle, R.J. : Role of sialic acid in the kinetics of Streptococcus sanguis adhesion to artificial pellicle. Infect. Immun., $55: 1552-1557,1987$.

18) Liljemark, W.F., Bloomquist, C.G., Fenner, L.J., Antonelli, P.J. and Coulter, M.C : Effect of neuraminidase on the adherence to salivary pellicle of Streptococcus sanguis and Streptococcus mitis. 
Caries Res., $23: 141-145,1989$.

19) Nyvad, B. and Kilian, M. : Comparison of the initial streptococcal microflora on dental enamel in caries-active and in caries-inactive individuals. Caries Res., 24:267-272, 1990.

20) Murray, P.A., Levine, M.J., Tabak, L.A. and Reddy, M.S. : Specificity of salivary-bacterial interactions. II. Evidence for a lectin on Streptococcus sanguis with specificity for a NeuAc $\alpha 2,3$ Gal $\beta 1$, 3 GalNAc sequence. Biochem. Biophys. Res. Commun., $106:$ 390-396, 1982.

21) Levine, M.J., Herzberg, M.C., Levine, M.S. Ellison, S.A., Stinson, M.W., Li, H.C. and van Dyke, T. : Specificity of salivary-bacterial interactions : Role of terminal sialic residues in the interaction of salivary glycoproteins with Streptococcus sanguis and Streptococcus mutans. Infect. Immun., $19: 107-115,1978$.

22) Morris, E.J. and McBride, B.C. : Adherence of Streptococcus suryuis to saliva-coated hydroxyapatite: Evidence for two binding sites. Infect. Immun., $43:$ 656-663, 1984.

23) Cisar, J.O., David, V.A., Curl, S.H. and Vatter, A. E. : Exclusive presence of lactose-sensitive fimbriae on a typical strain (WVU 45) of Actinomyces naeslundii, Infec. Immun., $46: 453^{-}$ 458, 1984.
24) Stinson, M.W., Safulko, K. and Levine, M.J. : Adherence of Porphyromonas (Bacteroides) gingivalis to Streptococcus sanguis in vitro. Infect. Immun., 59 : 102-108, 1991.

25) Grenier, D. and Mayrand, D. : Functional characterization of extracellular vesicles produced by Bacteroides gingivalis. Infect. Immun., $55: 111^{-}$ 117, 1987.

26) Ellen, R.P. and Grove, D.A. : Bacteroides gingivalis vesicles bind to and aggregate Actinomyces viscosus. Infect. Immun., $57: 1618^{-1620,} 1989$.

27) Kinder, S.A. and Holt, S.C. : Characterization of coaggregation between Bacteroides gingivalis T 22 and Fusobacterium nucleatum T 18 . Infect. Immun., $57: 3425-3433,1989$.

28) Takazoe, I., Matsukubo, T. and Katow, T. : Experimental formation of "Corn cob" in vitro. J. Dent. Res., 57 : 384-387, 1978.

29) Lancy, P. Jr., Dirienzo, J.M., Appelbaum, R., Rosan, B. and Holt, S.C. : Corncob formation between Fusobacterium nucleatum and Streptococcus sanguis. Infect. Immun., 40 : 303-309, 1983.

30) Watanabe, K., Yamaji, Y. and Umemoto, T. : Correlation between cell-adherent activity and surface structure in Porphyromonas gingivalis. Oral Microbiol. Immunol., 7 : 357-363, 1992.

連絡先：

朝日大学歯学部口腔病理学講座

₹ 501-0296 岐阜県本巣郡穂積町穂積 1851 